AL-MASHRAFIYAH: Jurnal Ekonomi, Keuangan, dan Perbankan Syariah

ISSN (p): 2597-4904 ISSN (e) : 2620-5661

Volume 3, Nomor 1, April (2019), h. 15-26

https://doi.org/10.24252/al-mashrafiyah.v3i1.7502

\title{
MENAKAR DAMPAK PEMBIAYAAN MUDHARABAH DAN MUSYARAKAH TERHADAP PROFITABILITAS RETURN ON ASSETS PT. BANK MUAMALAT INDONESIA Tbk.
}

\author{
Indah Wahyuningsih \\ Program Magister Ekonomi dan Keuangan Syariah Universitas Indonesia \\ indah.wahyuningsih@ui.ac.id
}

\begin{tabular}{ll}
\hline Keywords: & \multicolumn{1}{c}{ ABSTRACT } \\
Mudharabah, & This research was conducted to measure the impact of mudharabah and \\
Musyarakah, & musyarakah financing on profitability with the Return on Assets (ROA) ratio of \\
Profitability, and & PT. Bank Muamalat Indonesia Tbk. period of 2011-2017. The research method \\
Return on Assets. & used in this research is descriptive quantitative using multiple linear regression. \\
& Data used is secondary data in the form of financial statements of PT. Bank \\
& Muamalat Indonesia Tbk. which is accessed through the Otoritas Jasa Kenangan \\
& (OJK) website. The results showed that 51.3\% variables Profitability of return on \\
& assets (ROA) can be explained by mudharabah and musyarakah ratios. T test \\
& (partial test) shows that the mudarabah ratio variable has no significant effect on \\
profitability of return on assets (ROA), while the musyarakah ratio variable has a & significant effect on profitability of return on assets (ROA). This is because \\
& mudharabah financing is classified as risky financing, so Islamic banks must \\
& innovate in carrying out risk management. On the other band, Musharakah \\
& financing contributes greatly to the total income of Islamic banks and partially bas a \\
& significant effect on the profitability of Islamic banks.
\end{tabular}

Kata Kunci:

Mudharabah,

Musyarakah,

Profitabilitas, dan

Return on Assets

\section{ABSTRAK}

Penelitian ini dilakukan untuk menakar dampak pembiayaan mudharabah dan musyarakah terhadap profitabilitas dengan rasio Return on Assets (ROA) PT. Bank Muamalat Indonesia Tbk. periode 20112017. Metode penelitian yang digunakan adalah deskriptif kuantitatif dengan menggunakan regresi linier berganda. Data yang digunakan berupa data sekunder berupa laporan keuangan PT. Bank Muamalat Indonesia Tbk. yang diakses melalui website Otoritas Jasa Keuangan (OJK). Hasil penelitian menunjukkan bahwa 51,3\% variabel Profitabilitas return on asssets (ROA) dapat dijelaskan rasio mudharabah dan musyarakah. Uji T (uji parsial) menunjukkan bahwa variabel rasio mudarabah tidak berpengaruh signifikan terhadap profitabilitas return on assets (ROA), sedangkan variabel rasio musyarakah berpengaruh signifikan terhadap profitabilitas return on assets (ROA). Hal ini dikarenakan pembiayaan mudharabah tergolong pembiayaan yang beresiko, sehingga bank syariah haruslah berinovasi dalam melakukan menajemen resiko. Di sisi lain, pembiayaan musyarakah berkontribusi besar terhadap total pendapatan bank syariah dan secara parsial berpengaruh signifikan terhadap profitabilitas bank syariah. 
Indah Wahyuningsih. Menakar Dampak Pembiayaan Mudharabah dan...

\section{PENDAHULUAN}

Pasca krisis moneter (1997/1998), perbankan syariah mulai menjadi sistem perbankan alternatif di Indonesia, kendati bank syariah telah berdiri di Indonesia sejak 1992 sebagai antitesis sistem perbankan konvensional yang goyah ketika krisis moneter. Dalam kurun waktu satu dekade, perbankan syariah mengalami perkembangan yang mengesankan dan signifikan (Ismail, 2011). Prinsip/hukum perbankan syariah dianggap akan melahirkan keseimbangan sistem ekonomi karena dihilangkannya antara lain unsur gharar (spekulasi atau ketidakpastian). Di sini pemberi dana di samping turut berbagi keuntungan juga ikut berbagi kerugian. Uang hanya merupakan media pertukaran bukan lagi komoditas, karena tidak dianggap memiliki nilai intrinsik (Ismail, 2011).

Dasar pemikiran pengembangan bank berdasarkan prinsip bagi hasil adalah untuk memberikan pelayanan jasa kepada sebagian masyarakat Indonesia yang tidak dapat dilayani oleh perbankan yang sudah ada, karena bank-bank tersebut menggunakan sistem bunga. Dalam menjalankan operasinya, bank syariah tidak mengenal konsep bunga uang dan tidak mengenal peminjaman uang tetapi yang ada adalah kemitraan/kerjasama (mudharabah dan musyarakah) dengan prinsip bagi hasil, sementara peminjaman uang hanya dimungkinkan untuk tujuan sosial tanpa adanya imbalan apapun. Sehingga dalam operasinya dikenal beberapa produk bank syariah antara lain produk dengan prinsip mudharabah dan musyarakah. Prinsip mudharabah dilakukan dengan menyepakati nisbah bagi hasil atas keuntungan yang akan diperoleh sedangkan kerugian yang timbul menjadi resiko pemilik dana sepanjang tidak ada bukti bahwa pihak pengelola tidak melakukan kecurangan (Arifah, 2017). Mudharabah berarti ungkapan penyerahan harta milik seseorang kepada orang lain sebagai usaha (Fadhila, 2015). Pembiayaan mudharabah merupakan salah satu tonggak ekonomi syariah yang mewakili prinsip Islam untuk mewujudkan keadilan masyarakat melalui sistem bagi hasil (Susana, 2011).

Selain itu mudharabah dan musyarakah merupakan instrumen yang menarik di bank syariah. Mudharabah yang ditawarkan bank syariah amatlah cocok dibandingkan dengan pemberian kredit yang ada di bank konvensional, karena dengan sistem profit and loss sharing dan revenue sharing serta adanya ketentuan-ketentuan usaha atau manajemen yang diberikan oleh bank diharapkan untuk kepuasan dan transparasi. Pembiayaan musyarakah dan mudharabah dalam jumlah besar dapat membawa hasil yang menguntungkan bagi pihak bank, jika penyaluran pembiayaan tersebut dalam pengembaliannya berjalan dengan lancer (Fatminudin, 2018).

Transparansi bagi bank syariah bersifat mutlak dan harus dilakukan. Dengan adanya transparansi yang benar-benar transparan diharapkan akan semakin meningkatkan kepercayaan nasabah. Salah satu implementasi transparansi dalam operasional bank syariah adalah pembuatan laporan bagi hasil kepada semua deposan secara rutin setiap bulan. Dalam laporan bagi hasil antara lain dilaporkan berapa jumlah pendapatan yang diterima bank dalam satu bulan, yang akhirnya akan berpengaruh terhadap berapa nominal hasil investasi yang akan diterima deposan.

Dalam laporan bagi hasil, pengertian pendapatan adalah pendapatan riil, yaitu pendapatan yang benar-benar secara tunai telah diterima bank dari hasil penanaman dalam aktiva produktif, baik yang berupa pendapatan margin, pendapatan nisbah, maupun pendapatan sewa. Seperti yang diketahui, bahwa aktiva produktif bank syariah secara garis besar ada tiga macam, yaitu piutang yang akan menghasilkan margin, pembiayaan yang akan menghasilkan bagi hasil dan ijarah yang akan menghasilkan pendapatan sewa.

Setiap bank pasti menghimpun dana dan mengalokasikan dananya untuk kegiatan lain yang menghasilkan keuntungan. Salah satu pengalokasian dana tersebut adalah pembiayaan mudharabah dan musyarakah. Pembiayaan mudharabah dan musyarakah akan menghasilkan laba dari perhitungan bagi hasilnya. Keuntungan tersebut akan dibagi antara bank dan nasabah pengelolanya. Keuntungan tersebut akan digunakan untuk mengembalikan modal yang 
dialokasikan untuk pembiayaan. Tingkat pengembalian modal tersebut dapat mengukur tingkat profitabilitas suatu bank dengan cara memperbandingkan keuntungan/laba dan modal yang dimilikinya.

Profitabilitas secara umum terfokus pada hubungan antar hasil operasi seperti yang dilaporkan dalam laporan laba rugi dan sumber daya yang tersedia bagi perusahaan seperti yang dilaporkan dalam neraca (Dewi, 2010). Mengetahui tingkat profitabilitas perusahaan juga sangat penting bagi pihak manajemen. Karena dengan mengetahui tingkat profitabilitas perusahaan akan memudahkan pihak manajemen dalam mengambil keputusan berkaitan dengan perusahan.

Dengan demikian dapat diketahuai bahwa pendapatan bagi hasil pembiayaan mudharabah dan musyarakah mempunyai pengaruh terhadap profitabilitas bank tersebut. Hal ini mendorong penulis untuk meneliti tentang "Pengaruh Pendapatan Pembiayaan Mudharabah dan Musyarakah terhadap Profitabilitas Return on Assets (PT. Bank Muamalat Indonesia Tbk.". Adapun tujuan penelitian ini adalah untuk menguji dan menganalisis pengaruh pendapatan pembiayaan mudharabah dan musyarakah terhadap tingkat profitabilitas return on assets pada PT. Bank Muamalat Indonesia Tbk.

\section{LANDASAN TEORI}

\section{Mudharabah}

Sebagai makhluk sosial, kebutuhan akan kerja sama antara satu pihak dengan pihak lain guna meningkatkan taraf perekonomian dan kebutuhan hidup, atau keperluan-keperluan lain tidak bisa diabaikan. Kenyataan menunjukan bahwa di antara sebagian manusia memiliki modal, tetapi tidak bisa menjalankan usaha-usaha produktif, tetapi berkeinginan membantu orang lain yang kurang mampu dengan jalan mengalihkan sebagian modalnya kepada pihak yang memerlukan. Di sisi lain tidak jarang pula ditemui orang-orang yang memiliki kemampuan dan keahlian berusaha secara produktif, tetapi tidak memiliki atau kekurangan modal usaha. Berdasarkan kenyataan itulah, sangat diperlukan adanya kerja sama pemilik modal dengan orang-orang yang tidak mempunyai atau kekurangan modal.

Mudharabah adalah salah satu bentuk kerja sama dalam lapangan ekonomi, yang bisa pula disebut qiradh yang berarti al-qath' (potongan) (Trimulato, 2016). Menurut bahasa, Abdurrahman al-Jaziri berpendapat bahwa mudharabah berarti ungkapan terhadap pemberian harta dari seorang kepada orang lain sebagai modal usaha di mana keuntungan yang diperoleh akan dibagi di antara mereka berdua, dan bila rugi akan ditanggung oleh pemilik modal (Helmi Karim, 2002). Menurut istilah syarak, mudharabah berarti akad antara dua pihak untuk bekerja sama dalam usaha perdagangan di mana salah satu pihak memberikan dana kepada pihak lain sebagai modal usaha dan keuntungan dari modal usaha itu akan dibagi diantara mereka berdua sesuai dengan perjanjian yang telah disepakati (Helmi Karim, 2002).

Menurut Hasbi Ash Shiddieqy, mudharabah adalah semacam syarikat akad, bermufakat dua orang padanya dengan ketentuan: modal dari satu pihak, sedangkan usaha menghasilkan keuntungan dari pihak yang lain; dan keuntungannya dibagi di antara mereka (Hasbi Ash Shiddieqy, 1974). Dengan kata lain dapat pula disebutkan bahwa adalah akad antara dua orang yang berisi kesepakatan bahwa salah seorang dari mereka akan memberikan modal dari harta miliknya sendiri kepada pihak lain sebagai modal usaha-usaha produktif, dan keuntungan dari usaha itu akan diberikan sebagian kepada pemilik modal dalam jumlah tertentu sesuai dengan kesepakatan yang sudah disetujui bersama.

Secara teknis, mudharabah adalah akad kerja sama usaha antara dua pihak di mana pihak pertama (shahibul maal) menyediakan seluruh modal, sedangkan pihak lainnya menjadi pengelola. Keuntugan usaha secara mudharabah dibagi menurut kesepakatan yang dituangkan dalam kontrak, sedangkan apabila rugi ditanggung oleh pemilik modal selama kerugian itu 
Indah Wahyuningsih. Menakar Dampak Pembiayaan Mudharabah dan...

bukan akibat kelalaian si pengelola. Seandainya kerugian itu diakibatkan karena kecurangan atau kelalaian si pengelola, si pengelola harus bertanggung jawab atas kerugian tersebut (Muhammad Syafii Antonio, 2001).

\section{Musyarakah}

Musyarakah secara bahasa berarti mencampur. Dalam hal ini mencampur satu modal dengan modal yang lain sehingga tidak dapat dipisahkan satu sama lain. Musyarakah disebut juga dengan syirkab (Adrian Sutedi, 2009). Musyarakah adalah akad kerja sama antara dua pihak atau lebih untuk suatu usaha tertentu dimana masing-masing pihak memberikan kontribusi dana dengan kesepakatan bahwa keuntungan dan risiko akan ditanggung bersama sesuai dengan kesepakatan. (Al Arif, 2012).

Transaksi musyarakah dilandasi adanya keinginan para pihak yang bekerja sama untuk meningkatkan nilai aset yang mereka miliki secara bersama-sama. Semua bentuk usaha yang melibatkan dua pihak atau lebih dimana mereka secara bersama-sama memadukan seluruh bentuk sumber dana baik yang berwujud maupun tidak berwujud. Komposisi modalnya tidak harus sama. Namun biasanya porsi modal dapat menjadi acuan dalam menentukan porsi nisbah bagi hasilnya.

Karim (2006) menyatakan bahwa pembiayaan musyarakah merupakan semua bentuk usaha yang melibatkan dua pihak atau lebih dimana mereka secara bersama-sama memadukan seluruh bentuk sumber daya baik yang berwujud maupun tidak berwujud. Keuntungan dan kerugian ditanggung bersama sesuai dengan proporsi yang telah ditetapkan sebelumnya, Melalui pembiayaan bagi hasil yang disalurkan bank syariah akan memperoleh pendapatan berupa bagi hasil yang menjadi bagian bank. Dalam pembiayaan musyarakah, bank syariah tidak memberikan modal secara penuh, akan tetapi modal yang diberikan adalah sebagian dari total keseluruhan modal yang dibutuhkan.

\section{Profitabilitas}

Adapun manfaat profitabilitas yaitu: mengetahui besarnya tingkat laba yang diperoleh perusahaan dalam suatu periode, mengetahui posisi laba perusahaan tahun sebelumnya dan tahun sekarang, mengetahui perkembangan laba dari tahun ke tahun, mengetahui besarnya laba bersih sesudah pajak dengan modal sendiri dan mengetahui jumlah produktivitas dari seluruh dana perusahaan yang digunakan baik modal pinjaman maupun modal sendiri. Ada beberapa pengukuran terhadap profitabilitas perusahaan, dimana pengukuran dihubungkan dengan volume penjualan, total aktiva dan modal secara keseluruhan. Dari sudut pandang calon investor, indikator penting untuk menilai prospek perusahaan di masa yang akan datang adalah dari pertumbuhan profitabilitas perusahaan.

Menurut Munawir, profitabilitas adalah rasio yang menunjukkan kemampuan perusahaan dalam menghasilkan laba selama periode tertentu yang diukur dengan kesuksesan dan kemampuan perusahaan menggunakan aktivanya secara produktif. Analisis profitabilitas adalah evaluasi rasio kinerja operasi yang umumnya mengaitkan pos laporan laba rugi dengan penjualan (Munawir, 2004). Kemampuan dalam menghasilkan laba (profitabilitas) bagi Bank Syariah sangat berdampak dalam meningkatkan pertumbuhan Bank Syariah (Haq, 2015).

Profitabilitas erat kaitannya dengan tingkat loyalitas pelanggan. Mengapa loyalitas pelanggan penting bagi profitabilitas perusahaan? Pelanggan menjadi lebih menguntungkan ketika mereka makin lama menggunakan produk perusahaan dalam masing-masing jasa yang ditawarkan tersebut. Laporan keuangan merupakan alat yang sangat penting untuk memperoleh informasi sehubungan dengan posisi keuangan perusahaan yang bersangkutan. Data tersebut akan lebih berarti bagi pihak-pihak yang berkepentingan apabila data tersebut diperbandingkan dua periode atau lebih, dan dianalisis lebih lanjut sehingga dapat diperoleh data yang akan mendukung keputusan yang akan diambil (Christopher, 2010). 
Profitabilitas merupakan alat yang digunakan untuk menganalisis kinerja manajemen, tingkat profitabilitas akan menggambarkan posisi laba perusahaan. Para investor di pasar modal sangat memperhatikan kemampuan perusahaan dalam menghasilkan dan meningkatkan laba, hal ini merupakan daya tarik bagi investor dalam melakukan jual beli saham, oleh karena itu manajemen harus mampu memenuhi target yang telah ditetapkan.

Rasio profitabilitas merupakan perbandingan antara laba perusahaan dengan investasi atau ekuitas yang digunakan untuk memperoleh laba tersebut. Rasio profitabilitas menunjukkan kemampuan perusahaan untuk menghasilkan laba dalam hubungannya dengan penjualan, total aktiva, maupun modal sendiri. Semakin tinggi profitabilitas perusahaan semakin tinggi efisiensi perusahaan tersebut dalam memanfaatkan fasilitas perusahaan.

Laba merupakan salah satu tolok ukur keberhasilan kinerja perusahaan. Selain itu, laba juga sering dijadikan salah satu indikator yang dilihat para investor sebelum mereka menginvestasikan dana mereka karena laba menggambarkan kemampuan perusahaan untuk memenuhi kewajiban mereka kepada pemegang saham.

Bagi perusahaan, laba menjadi hal yang penting karena laba menjadi salah satu faktor yang mempengaruhi struktur modal perusahaan guna melaksanakan kegiatan operasional perusahaan tersebut. Analisis profitabilitas perusahaan merupakan bagian utama dari laporan keuangan. Seluruh laporan keuangan dapat digunakan untuk analisis profitabilitas dan yang paling penting adalah laporan laba rugi. Laporan laba rugi melaporkan hasil operasi perusahaan selama satu periode.

Profitabilitas perusahaan diukur berdasarkan ratio antara laba setelah pajak dengan total aktiva. Rasio ini disebut dengan Return on Asset. Return on asset mengukur kemampuan perusahaan menghasilkan laba bersih pada tingkat aset tertentu. Return On asset mengukur kemampuan perusahaan dalam memanfaatkan aktivanya untuk memperoleh laba. Dapat disimpulkan bahwa return on total asset merupakan suatu ukuran yang dapat digunakan untuk menentukan seberapa besar laba yang diperoleh suatu perusahaan atas pemanfaatan aktiva dalam suatu periode waktu tertentu. ROA yang tinggi menunjukkan efisiensi dan efektivitas pengelolaan aset suatu perusahaan semakin baik.

\section{METODE PENELITIAN}

Penelitian ini menggunakan metode kuantitatif deskriptif. Metode deskriptif merupakan metode yang digunakan untuk menggambarkan atau menganalisis suatu hasil penelitian tetapi tidak digunakan untuk membuat kesimpulan yang lebih luas (Sugiyono, 2001).

Metode pengumpulan data yang digunakan dalam penelitian ini adalah metode nonprobability sampling yaitu sebuah teknik sampling yang tidak memberikan kesempatan atau peluang yang sama pada setiap anggota populasi untuk dipilih menjadi sampel (Sarjono dan Julianita, 201). Pengambilan sampel dilakukan atas dasar pertimbangan peneliti (purposive sampling) yang menganggap unsur-unsur yang dikehendaki telah ada dalam anggota sampel yang diambil. Populasi yang menjadi objek penelitian adalah laporan keungan bank syariah yang terdaftar di Bank Indonesia dari tahun 2011-2017 dengan tingkat presentase profitabilitas yang sesuai dengan peraturan Bank Indonesia.

Syarat dan kriteria yang harus dipenuhi agar dapat digunakan sebagai sampel penelitian ini, diantaranya adalah bank syariah yang terdaftar di Bank Indonesia, secara rutin mempublikasi laporan keuangan triwulan selama periode kuartal I tahun 2011 sampai dengan kuartal IV tahun 2017, memiliki kelengkapan data berdasarkan variabel yang diteliti. Berdasarkan syarat dan kriteria tersebut peneliti menetapkan sampel yang digunakan dalam penelitian ini adalah sebanyak masing-masing 28 laporan keuangan, yang terdiri dari laporan 
Indah Wahyuningsih. Menakar Dampak Pembiayaan Mudharabah dan...

laba rugi triwulanan dan laporan posisi keuangan (neraca) triwulanan. Laporan keuangan tersebut diakses melalui website Otoritas Jasa Keuangan (OJK).

Data yang diperoleh kemudian diolah dan dianalisis mengunakaan aplikasi komputer Statistical Package for the Social Sciences (SPSS) versi 20 untuk Mac OS. Analisis dilakukan menggunakan uji asumsi klasik yang terdiri dari uji multikolinearitas dan uji heteroskedastisitas. Uji multikolinieritas dilakukan untuk memastikan multikolinieritas masing-masing data. Data yang baik menunjukan tidak terjadinya hubungan yang kuat (interkorelasi) antar variabel independen sehingga bisa dilanjutkan dengan uji regresi linear berganda.

Uji multikolerinearitas bertujuan untuk mengetahui apakah terjadi interkorelasi (hubungan yang kuat) antar variabel independen. Jika tidak terjadi interkorelasi antar variabel independen maka model regresi dinyatakan baik dan bisa dilanjutkan dengan uji regresi linear berganda. Tolerance (TOL) dan Variance Inflation Factor (VIP) digunakan untuk mendeteksi ada atau tidaknya gejala mulikolinearitas. Sedangkan uji heteroskedastisitas bertujuan untuk menguji apakah dalam model regresi terjadi ketidaksamaan variabel dari residual suatu pengamatan kepengamatan yang lain. Pengujian heteroskedastisitas dilakukan berdasarkan scatterplots dari hasil pengolahan data dengan SPSS.

Setelah memenuhi uji asumsi klasik, analisis dilanjutkan dengan analisis regresi linear berganda adalah pengukuran pada penghitungan kontribusi setiap variabel independen terhadap variabel dependen secara bersamaan. Penerapan umumnya adalah untuk mengukur tingkat korelasi antar variabel (Galloway, 2004).

Dasar pengambilan keputusan dalam uji regresi berganda terdiri dari uji simultan (uji F), uji parsial (uji t), dan uji koefisien determinasi $\left(\mathrm{R}^{2}\right)$. Metode kuadrat terkecil digunakan untuk memperkirakan kemiringan dan intersepsi sumbu y dari garis regresi sementara koefisien determinasi $\left(\mathrm{R}^{2}\right)$ digunakan untuk menguji kontribusi variabel independen terhadap variansi variabel dependen (Fah dan Hoon, 2009). Adapun model persamaan regresi linear berganda sebagai berikut:

$$
\mathrm{Y}=\boldsymbol{\beta}_{0}+\beta_{1} \text { Mudharabah }+\beta_{2} \text { Musyarakah }+\mathrm{U}_{\mathrm{i}}
$$

Dimana:

$\begin{array}{ll}\mathrm{Y} & =\text { Profitabilitas Return on Assets } \\ \beta_{0} & =\text { Konstanta } \\ \beta_{1} & =\text { Koefisien dari rasio mudharabah } \\ \beta_{2} & =\text { Koefisien dari rasio musyarakah } \\ \mathrm{U}_{\mathrm{i}} & =\text { Kesalahan Random }\end{array}$

HASIL DAN PEMBAHASAN

Tabel 1. Rasio Mudharabah, Musyarakah, dan Return on Assets (ROA)

\begin{tabular}{ccccc}
\hline \multicolumn{2}{c}{ Data } & Rasio Mudharabah & Rasio Musyarakah & $\begin{array}{c}\text { Return on Assets } \\
\text { (ROA) }\end{array}$ \\
\hline Tahun & Bulan & & 0,7606 & 0,0237 \\
\hline 2011 & Maret & 0,2394 & 0,7770 & 0,0238 \\
& Juni & 0,2230 & 0,7870 & 0,0224 \\
2012 & Sept & 0,2130 & 0,7884 & 0,0206 \\
& Des & 0,2116 & 0,8085 & 0,0245 \\
& Maret & 0,1915 & 0,8207 & 0,0271 \\
& Juni & 0,1793 & 0,8267 & 0,0276 \\
\hline
\end{tabular}


AL-MASHRAFIYAH: Jurnal Ekonomi, Keuangan, dan Perbankan Syariah Volume 3, Nomor 1, April 2019

\begin{tabular}{clccc}
\hline \multicolumn{2}{c}{ Data } & Rasio Mudharabah & Rasio Musyarakah & $\begin{array}{c}\text { Return on Assets } \\
\text { (ROA) }\end{array}$ \\
\hline \multirow{2}{*}{2013} & Bulan & 0,1687 & 0,8313 & 0,0250 \\
& Des & 0,1474 & 0,8526 & 0,0271 \\
& Maret & 0,1442 & 0,8558 & 0,0292 \\
& Juni & 0,1528 & 0,8472 & 0,0303 \\
& Sept & 0,1552 & 0,8448 & 0,0292 \\
& Des & 0,1732 & 0,8268 & 0,0340 \\
& Maret & 0,1433 & 0,8991 & 0,0330 \\
& Juni & 0,1096 & 0,8904 & 0,0274 \\
& Sept & 0,1118 & 0,9208 & 0,0108 \\
& Des & 0,1011 & 0,8989 & 0,0011 \\
& Maret & 0,1066 & 0,8934 & 0,0019 \\
& Juni & 0,0953 & 0,9047 & 0,0027 \\
& Sept & 0,0903 & 0,8779 & 0,0026 \\
& Des & 0,0929 & 0,9071 & 0,0005 \\
& Maret & 0,0785 & 0,9215 & 0,0006 \\
& Juni & 0,0630 & 0,9370 & 0,0007 \\
& Sept & 0,0548 & 0,9452 & 0,0014 \\
& Des & 0,0746 & 0,9254 & 0,0002 \\
& Maret & 0,0477 & 0,9523 & 0,0005 \\
& Juni & 0,0493 & 0,9507 & 0,0006 \\
& Sept & 0,0494 & 0,9506 & 0,0004 \\
\hline
\end{tabular}

Sumber: Analisis data sekunder setelah diolah, Tahun 2018

Tabel 1 di atas berisi data analisis data sekunder yang telah dioleh oleh peneliti. Data tersebut terdiri dari data triwulanan sejak Maret 2011 sampai dengan Desember 2017, yang terdiri dari 28 data yang telah diolah dari data laporan keuangan publikasi Bank Muamalat Indonesia Tbk. Bisa dilihat bahwa untuk rasio mudharabah mengalami penurunan konstan setiap tahunnya, sedangkan rasio musyarakah mengalami kenaikan setiap tahunnya. Untuk return on assets Bank Muamalat Indonesia Tbk. mengalami penurunan konstan setiap tahunnya. Hal ini menandakan bahwa terjadi penurunan kemampuan bank dalam mengelola asset yang dimiliki guna memciptakan profit.

Analisis uji prasyarat dalam penelitian ini yaitu mengunakan uji asumsi klasik sebagai salah satu syarat dalam mengunakan analisis regresi. Adapun pengujiannya dapat dibagi dalam beberapa tahap yaitu, uji multikolenearitas dan uji heteroksedastisitas. Berdasarkan hasil uji multikolonieritas, diketahui nilai VIF untuk masing- masing variabel rasio mudharabah dan rasio musyarakah memiliki nilai VIF nya $<10$ dan nilai toleransinya $>0,10$ sehingga model dinyatakan tidak terjadi multikolonieritas. Sedangkan hasil uji heteroksedastisitas diperoleh hasil Scatterplot, terlihat titik-titik menyebar secara acak dan tidak membentuk suatu pola tertentu yang jelas, serta tersebar baik diatas maupun dibawah angka 0 pada sumbu Y. Hal ini berarti tidak terjadi heteroksedastisitas pada model regresi, sehingga model regresi layak dipakai untuk memprediksi pengaruh variabel berdasarkan masukan variabel independennya. 
Indah Wahyuningsih. Menakar Dampak Pembiayaan Mudharabah dan...

Tabel 2. Hasil Analisis Regresi Linear Berganda

\begin{tabular}{lccccc}
\hline $\begin{array}{c}\text { Variabel } \\
\text { Independen }\end{array}$ & $\begin{array}{c}\text { Tanda Harapan } \\
\mathbf{( T H )}\end{array}$ & $\begin{array}{c}\text { Koefisien } \\
(\boldsymbol{\beta})\end{array}$ & t-hitung & Sig. & VIF \\
\hline Rasio Mudharabah & - & $-0,007$ & $-0,635$ & 0,531 & 1,048 \\
Rasio Musyarakah & - & $-0,163$ & $-5,214$ & 0,000 & 1,048 \\
\hline Konstanta & & & & & 0,159 \\
F-hitung & & & & & 15,206 \\
Adjusted R $^{2}$ & & & & & 0,513 \\
Sampel (n) & & & & & 28 \\
Taraf Signifikan $(\alpha)$ & & & & 0,000 \\
\hline
\end{tabular}

Sumber: Analisis data sekunder setelah diolah, Tahun 2018

Berdasarkan hasil olah data pada Tabel 2 di atas, diperoleh nilai koefisien determinasi yang disesuaikan yang disimbolkan dengan (Adjusted $\mathrm{R}^{2}$ ) sebesar 0,513 dengan kata lain hal ini menunjukkan bahwa besar persentase variasi profitabilitas return on assets yang bisa dijelaskan oleh variasi dari kedua variabel bebas yaitu rasio mudharabah dan rasio musyarakah sebesar 51,3 persen sedangkan sisanya sebesar 48,7 persen dijelaskan oleh variabel-variabel lain di luar model penelitian.

Berdasarkan Tabel 1, dapat dilihat hasil koefisien regresi $(\beta)$ di atas, maka diperoleh persamaan regresi sebagai berikut :

$$
\text { Return on Assets }=0,159-0,007 \text { Mudharabah - 0,163 Musyarakah }+\mathrm{U}_{\mathrm{i}}
$$

Dari hasil persamaan regresi di atas dapat dilihat bahwa nilai koefisien $\beta_{0}$ sebesar 0,159 yang berarti jika variabel Rasio Mudharabah $\left(\mathrm{X}_{1}\right)$ dan Rasio Musyarakah $\left(\mathrm{X}_{2}\right)$, adalah konstan atau $\mathrm{X}=0$ maka Profitabilitas Return on Assets adalah sebesar 0,159. Selanjutnya nilai koefisien $\beta_{1}$ adalah -0,007 yang artinya adalah apabila Rasio Mudharabah mengalami kenaikan sebesar 1 poin maka Profitabilitas Return on Assets mengalami penurunan sebesar 0,007. Koefisien bernilai negatif yang artinya terjadi hubungan negatif antara Rasio Mudharabah dan Profitabilitas Return on Assets. Hubungan negatif ini dikarenakan resiko dari pembiayaan Mudharabah bila terjadi kerugian akan berdampak pada tingkat pengembalian modal tersebut (Reinissa, 2015).

Dari Tabel 2 dapat dilihat bahwa variabel Rasio Mudharabah memiliki nilai p-value atau nilai signifikansi 0,531 di mana nilai tersebut lebih besar dari level of significant yaitu 0,05. Di mana $\mathrm{H}_{0}: \beta_{1}=0$ dan $\mathrm{H}_{1}: \beta_{1} \neq 0$ sehingga diputuskan bahwa $\mathrm{H}_{0}$ diterima. Sehingga dapat disimpulkan bahwa Rasio Mudharabah tidak mempengaruhi Profitabilitas Return on Assets secara signifikan. Hasil penelitian ini konsisten dengan studi empiris yang dilakukan oleh Wahyuningsih (2017), dalam penelitiannya, pembiayaan mudharabah memiliki pengaruh yang positif dan signifikan terhadap profitabilitas return on assets (ROA). Hal ini dikarenakan jumlah pembiayaan mudharabah pada PT. Bank Muamalat Indonesia selama periode 2011-2017 mengalami penurunan setiap tahunnya. Salah satu penyebab penurunan ini adalah karena ketidakmampuan mengelola resiko pembiayaan.

Selain itu, pembiayaan mudharabah terbilang memiliki resiko yang tinggi karena, bank syariah berpotensi mengalami kerugian modal dari usaha yang dijalankan nasabah apabila kerugian tersebut tidak diakibatkan oleh kelalaian nasabah sebagai pengelola dana. Hasil penelitian ini berbeda dengan penelitian yang dilakukan oleh Fadholi (2015) yang berjudul "Pengaruh pembiayaan murabahah, musyarakah dan mudharabah terhadap profitabilitas Bank Umum Syariah." Sampel yang digunakan merupakan data dari tahun 2011 sampai 2014. Pembiayaan mudharabah memberikan pengaruh positif dan signifikan terhadap tingkat ROA secara parsial. Hal ini terjadi karena, setiap tahunnya pendapatan pembiayaan mudharabab tidak 
lagi berkontribusi besar dalam total pendapatan dari pembiyaan bagi hasil. Sehingga terjadi penurunan rasio mudharabah sehingga pembiayaan mudharabah tidak lagi berpengaruh signifikan terhadap profitabilitas return on assets (ROA) bank syariah.

Selanjutnya, dapat dilihat pada tabel di atas bahwa nilai koefisien $\beta_{2}$ adalah - 0,163 yang artinya adalah apabila Rasio Musyarakah mengalami kenaikan sebesar 1 poin maka Profitabilitas Return on Assets mengalami penurunan sebesar 0,163. Koefisien bernilai negatif yang artinya terjadi hubungan negatif antara Rasio Musyarakah dan Profitabilitas Return on Assets. Dari Tabel 2 dapat dilihat bahwa variabel Rasio Musyarakah memiliki nilai $p$-value atau nilai signifikansi 0,000 di mana nilai tersebut lebih kecil dari level of significant yaitu 0,05 . Di mana $\mathrm{H}_{0}: \beta_{1}=0$ dan $\mathrm{H}_{1}: \beta_{1} \neq 0$ sehingga diputuskan bahwa $\mathrm{H}_{0}$ ditolak. Sehingga dapat disimpulkan bahwa Rasio Musyarakah tmempengaruhi Profitabilitas Return on Assets secara signifikan. Hasil penelitian ini konsisten dengan studi empiris yang dilakukan Reinissa (2015), Permata, Yaningwati, \& Zahroh (2012) sementara hasil penelitian ini tidak konsisten dengan temuan dari Hadiyati (2013) yang mengatakan bahwa musyarakah tidak berpengaruh signifikan terhadap profitabilitas.

Bisa dilihat pada tabel 1, rasio musyarakah mengalami peningkatan setiap tahunnya. Hal ini menunjukan bahwa bagi hasil pembiayaan musyarakah berkontribusi besar terhadap pendapatan pembiayaan bank syariah sehingga berimplikasi pada dampak signifikan terhadap profitabilitas return on assets (ROA). Musyarakah adalah akad kerja sama antara dua pihak atau lebih untuk suatu usaha tertentu dimana masing-masing pihak memberikan kontribusi dana dengan kesepakatan bahwa keuntungan dan risiko akan ditanggung bersama sesuai dengan kesepakatan. (Al Arif, 2012). Transaksi musyarakah dilandasi adanya keinginan para pihak yang bekerja sama untuk meningkatkan nilai aset yang mereka miliki secara bersama-sama. Semua bentuk usaha yang melibatkan dua pihak atau lebih dimana mereka secara bersama-sama memadukan seluruh bentuk sumber dana baik yang berwujud maupun tidak berwujud. Komposisi modalnya tidak harus sama. Namun biasanya porsi modal dapat menjadi acuan dalam menentukan porsi nisbah bagi hasilnya. Berbeda dengan pembiayaan mudharabah yang hanya menyertakan modal dari bank, pembiayaan musyarakah menyertakan modal dari kedua pihak. Sehingga hal ini menjadi kontrol untuk pengelolah usaha dalam menjalankan usahanya dengan baik. Melalui skema pembiayaan seperti ini, asset yang dimiliki bank syariah dapat berkembang dan berimplikasi pada kemampuan bank dalam mengelolah modalnya.

Uji F dengan menggunakan SPSS 20 memperoleh hasil yang dapat dilihat pada tabel 3 di atas. Hasil Uji F menunjukan bahwa secara bersama-sama atau simultan, variabel independen (rasio mudharabah dan musyarakah) berpengaruh terhadap variabel dependen jika pvalue (pada kolom signifikan) lebih kecil dari level of significant yaitu 5\% atau 0,05. Pada tabel 3 di atas dapat dilihat bahwa nilai p-value adalah 0,000 . Hal ini menunjukan bahwa p-value tersebut lebih kecil dari level of significant yang telah ditentukan sebesar 0,05. Dapat disimpulkan bahwa rasio mudharabah dan musyarkah secara simultan atau bersama-sama berpengaruh terhadap profitabilitas return on assets (ROA).

\section{PENUTUP}

Berdasarkan hasil analisis data yang dilakukan maka dapat diambil kesimpulan sebagai berikut : Secara parsial, pembiayaan Mudharabah memiliki pengaruh negatif dan tidak signifikan terhadap profitabilitas Bank Muamalat Indonesia Tbk. yang diukur dengan Return on Assets. Pengaruh negatif ini dikarenakan resiko dari pembiayaan Mudharabah bila terjadi kerugian akan berdampak pada tingkat pengembalian modal tersebut. Hasil penelitian menunjukkan bahwa pembiayaan Musyarakah berpengaruh negatif dan signifikan terhadap profitabilitas profitabilitas Bank Muamalat Indonesia Tbk. Sedangkan pembiayaan Murabahah tidak signifikan sehingga tidak berpengaruh terhadap profitabilitas BPR Syariah. Hasil pengujian menunjukkan bahwa 
Indah Wahyuningsih. Menakar Dampak Pembiayaan Mudharabah dan...

secara simultan pembiayaan Mudharabah dan Musyarakah berpengaruh signifikan terhadap profitabilitas profitabilitas Bank Muamalat Indonesia Tbk.

Oleh karenanya penulis memberikan beberapa rekomendasi berdasarkan hasil analisis data yang telah dilakukan, di antaranya adalah perlu adanya optimalisasi strategi yang dilakukan oleh Bank Muamalat Indonesia Tbk. dalam meningkatkan profitabilitas bank sehingga dapat meningkatkan pendapatan dan profitabilitas bagi bank. Selain itu, pada pembiayaan Mudharabah seharusnya ada pengkajian kembali dan lebih dikembangkan sehingga akan menarik minat nasabah dalam bekerjasama, karena akan berpengaruh terhadap pendapatan yang diterima oleh pihak bank. Begitu pula pada pembiayaan Musyarakah, lebih dikembangkan karena karakteristik utama perbankan syariah adalah sistem bagi hasil yang menjadi pembeda dari perbankan konvensional.

\section{DAFTAR PUSTAKA}

Al Arif, M.N.R. 2012. Lembaga Kenangan Syariab: Suatu Kajian Teoritis Praktis. Bandung: Pustaka Setia

Fadholi, A. D., \& Akt, A. A. (2015). Pengaruh Pembiayaan Murabahah, Musyarakah dan Mudharabah Terhadap Profitabilitas Bank Umum Syariah di Indonesia (Studi Empiris Pada Bank Umum Syariah di Indonesia Tahun 2011-2014) (Doctoral dissertation, Universitas Muhammadiyah Surakarta).

Antonio, M. S. I. (2001). Bank Syariah: dari teori ke praktik. Gema Insani.Arifah, O. N. (2017).

Arifah, O. N. (2017). Analisis Pembiayaan Mudharabah Bermasalah Pada Bmt Mitra Hasanah Semarang. Jurnal Jurisprudence, 7(1), 40-46. https://doi.org/10.23917/jurisprudence.v7i1.4354

Dewi, D. R., \& PRASETIONO, P. (2011). Faktor-Faktor Yang Mempengarubi Profitabilitas Bank Syariah Di Indonesia (Doctoral Dissertation, Universitas Diponegoro). https://Doi.Org/10.15408/Akt.V9i1.3584

Ismail, MBA., Ak., Drs. 2011. Perbankan Syariah. Jakarta: Prenada Media Group.

Fah, L.Y. and K.C. Hoon, 2009. Introduction to computer data analysis with SPSS 16.0 for windows. Selangor: Venton Publishing.

Fadhila, N. (2015). Analisis Pembiayaan Mudharabah dan Murabahah terhadap Laba. Jurnal Riset Akuntansi Dan Bisnis, 15(1), 65-77.

Fatminudin, S. F. (2018). Pengaruh Tingkat Risiko Pembiayaan Mudharabah dan Murabahah terhadap Tingkat Profitabilitas Bank Syariah. Jurnal RELASI STIE Mandala Jember, $4(1)$.

Galloway, F.J., 2004. The secrets behind producing meaningful quantitative research.

Hadiyati, P. (2013). Pengaruh Non Performing Fanancing Pembiayaan Mudharabah dan Musyarakah Bank Muamalat Indonesia, 1(1), 1-23.

Haq, R. N. A. (2015). Pengarub Pembiayaan Dan Efisiensi Terbadap Profitabilitas Bank Umum Syariah. Perbanas, 1(November), 107-124. 
AL-MASHRAFIYAH: Jurnal Ekonomi, Keuangan, dan Perbankan Syariah

Hadiyati, P. (2013). Pengaruh Non Performing Fanancing Pembiayaan Mudharabah dan Musyarakah Bank Muamalat Indonesia, 1(1), 1-23.

Karim, Helmi, 2002. Figh Muamalah, Jakarta: PT. Raja Grafindo Persida.

Karundeng, Zulkarnain, 2016, "Pengarub Pendapatan Mudharabah dan Musyarakah terhadap Profitabilitas Bank BRI Syariah." Skripsi. Manado: Fakultas Ekonomi dan Bisnis Islam IAIN Manado.

Lovelock, Christopher 2010. Pemasaran Jasa-Prespektif Indonesia, Surabaya: Erlangga.

Ziqri, M. (2009). Analisis pengaruh pendapatan murabahah, mudharabah dan musyarakah terhadap profitabilitas Bank.

Muhammad Ayub, 2009. Understanding Islamic Finance, Terj. Aditya Wisnu Pribadi. Jakarta: PT Gramedia Pustaka Utama.

Munawir, 2004. Analisis Laporan Kenangan, Yogyakarta: Liberty Yogyakarta.

Nurlita, Iin, 2009. Pengaruh Pendapatan Bagi Hasil Pembiayaan Mudharabah Terbadap Profitabilitas Pada PT. Bank Muamalat Indonesia Tbk. Universitas Mercu Buana.

Permata, R. I. D., Yaningwati, F., \& Zahroh. (2012). Analisis Pengaruh Pembiayaan Mudharabah dan Musyarakah terhadap Profitabilitas (Return On Equity) (Studi pada Bank Umum Syariah Yang Terdaftar di Bank Indonesia Periode 2009-2012). Administrasi Bisnis, 12(1), 1-9.

Rahman, A.F. dan Rochmanika, R. 2012. "Pengaruh Pembiayaan Jual Beli, Pembiayaan Bagi Hasil, dan Rasio NonPerforming Financing Terhadap Profitabilitas Bank Umum Syariah di Indonesia". Jurnal Ekonomi. Malang: Universitas Brawijaya.

Reinissa, R. D. (2015). Pengaruh Pembiayaan Mudharabah , Musyarakah, dan Murabahah Terhadap Profitabilitas Bank Syariah Mandiri, Tbk. Jurnal Ilmiah, 175-183.

Russely Inti Dwi Permata, Fransisca Yuningwati Zahroh Z.A., 2014, Analisis Pengaruh Pembiayaan Mudharabah dan Musyarakah Terhadap Tingkat Profitabilitas (Return on Equity) Studi Pada Bank Umum Syariah yang terdaftar di Bank Indonesia Periode 2009-2012. Jurnal Administrasi Bisni (JAB) Vol 12.

Sari, D. W., \& Anshori, M. Y. (2016). Pengarub Pembiayaan Murabahah, Istishna, Mudharabah, Dan Musyarakah Terhadap Profitabilitas (Studi Pada Bank Syariah Di Indonesia Periode Maret 2015 - Agustus 2016), 1-8.

Sarjono, H., Julianita, W. (2011). SPSS vs Lisrel: Sebuah pengantar, Aplikasi Untuk Riset. Jakarta: Salemba Empat.

Shiddieqy, Hasbi Ash, 1974. Pengantar Figh Muamalat, Jakarta: Bulan Bintang.

Sugiyono, 2001. Analisis Metode Penelitian Kualitatif dan Kuantitatif. Jakarta: Penerbit Bina Pustaka.

Sugiyono, 2007. Statistika Untuk Penelitian. Bandung: CV. Alfabeta. 
Indah Wahyuningsih. Menakar Dampak Pembiayaan Mudharabah dan...

Sutedi, A. 2009. Perbankan Syariah Tinjanan Dan Beberapa Segi Hukum. Jakarta: Ghalia Indonesia.

Susana, E. \& A. P. (2011). Pelaksanaan dan Sistem Bagi Hasil Pembiayaan Al-Mudharabah pada Bank Syariah. Jurnal Keuangan Dan Perbankan, 15(3), 466-478.

Wahyuningsih, Indah., 2017. Pengaruh Pendapatan Pembiayaan Mudharabah terhadap Profitabilitas Return on Assets (ROA) PT. Bank Muamalat Indonesia Tbk. Periode 2011-2015. Journal Tasharruf: Journal onf Economic and Bussiness of Islam. Vol. 2. No. 2. Desember 2017. 